
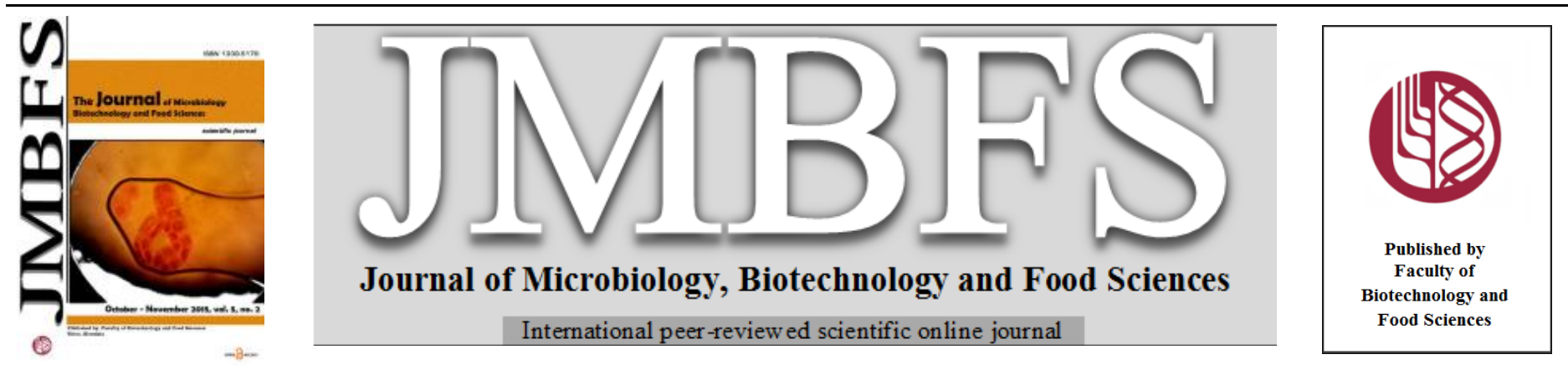

\title{
EFFICACY OF SYMBIOSIS FORMATION BY PEA PLANTS WITH LOCAL WESTERN UKRAINIAN STRAINS OF RHIZOBIUM
}

\author{
Ulyana Ya. Stambulska ${ }^{a}$, Volodymyr I. Lushchak ${ }^{a, *}$
}

Address(es):

${ }^{a}$ Department of Biochemistry and Biotechnology, Precarpathian National University named after Vasyl Stefanyk, 57 Shevchenko Str., Ivano-Frankivsk 76025, Ukraine. Tel/Fax.: +38 0342714683 .

*Corresponding author: lushchak@pu.if.ua

doi: 10.15414/jmbfs.2015.5.2.92-98

\section{ARTICLE INFO}

Received 25. 3. 2015

Revised 20.5. 2015

Accepted 9. 6. 2015

Published 1. 10. 2015

Regular article open 2 ACCESS

\section{ABSTRACT}

The chemotaxic activity and the effect of nodule bacteria strains, isolated from pea plants (Pisum sativum L.) in Western Ukraine, on legume-rhizobium symbiosis efficacy were studied. Two nodule strains were selected, RRL8 and RRL9, and their effects on the plants were compared to plants treated with the standard collection Rhizobium leguminosarum 245a strain. Sucrose, aspartic acid, serine, glycine, and valine were the most effective attractants for the selected bacteria strains among the various carbohydrates, organic acids and amino acids tested. Seeds inoculated with RRL8 and RRL9 isolates showed higher plant wet mass and number of nodules in comparison to controls and to plants inoculated with the 245a strain. The concentration of chlorophyll $a$ at the budding stage in plants inoculated with the RRL9 strain was higher than that of control and 245a inoculated strain plants. Treatment of pea seeds by local and 245a strains did not affect the anthocyanin concentration in leaves over the whole ontogenesis period of the pea plants. At the stage of 45 leaves in pea plants inoculated with RRL8 and 245a strains starch content was lower than that in control. Maximum pea grain crop was observed in plants inoculated with the RRL8 bacterial strain. It can be concluded, that pea nodule bacteria form an effective legume-rhizobium symbiosis and use of the local strains gives an increase in harvest under local climatic and soil conditions, which are the natural ecological niche for those bacterial strains.

Keywords: Rhizobium leguminosarum bv. viciae; nitrogen fixation; pea; chemotaxis; pigments; starch

\section{INTRODUCTION}

Biological fixation of atmospheric nitrogen is an important component of sustainable agriculture systems (Sessitsch et al., 2002; Patyka et al., 2003; Karunakaran et al., 2009). Gram-negative bacteria of the genus Rhizobium are among the most effective in nitrogen fixation. They are well known for capacity to establish a symbiosis with legume plants (Patriarca $\boldsymbol{e t}$ al., 2002; Spaynk $\boldsymbol{e}$ al., 2002; Gage, 2004). Rhizobia form specialized organs, called nodules, on roots of their hosts to reduce atmospheric nitrogen and make it available for plants (Patyka et al., 2003). The plant supplies the bacteria with energy and plastic materials, whereas bacteria reduce molecular nitrogen to $\mathrm{NH}_{4}{ }^{+}$, providing it to the plants for assimilation into amino acids, proteins, and other essential nitrogenous compounds (Gresshoff, 2003; Trainer et al., 2010).

Pea is one of the major legume crops and essential source of protein for humans (Morgun et al., 2007). The yield of a pea crop to big extent depends on the efficacy of its symbiosis with nodule bacteria, activity and competitiveness of bacterial strain, ground-climatic conditions, etc. (Mandrovskaya et al., 1994). Inoculation of seeds with active rhizobial strains is used to increase nitrogen accumulation and productivity of legumes (Krugova $\boldsymbol{e t}$ al., 1994). However, the used strains have to compete successfully with the local rhizobial strains and to maintain the activity under adverse conditions (Morgun and Kots, 2008). Highly efficient strains of nodule bacteria give the opportunity to create new fertilizers and to increase the crop capacity. Therefore, the selection of highly efficient strains of nitrogen-fixing bacteria is of key importance for increasing the efficiency of biological nitrogen fixation. Hence, the aim of this work was to isolate new nodule bacteria strains from pea plants of Western Ukraine and to investigate their influence on legume-rhizobium symbiosis efficacy.

\section{MATERIALS AND METHODS}

\section{Collection of root nodules from pea plants}

Root nodules were collected in July 2006, from flowering pea plants in different regions of Ivano-Frankivsk district. The nodules were excised from roots, soil debris was brushed off and then nodules were sterilized for 1 min in $95 \%$ ethanol. The nodules were further rinsed with sterile distilled water three times for $1 \mathrm{~min}$. The internal nodule content was added to sterile distilled water, mixed and spread on a Fred agar plate. The Fred medium contained $10 \mathrm{~g} / \mathrm{l}$ glucose, $0.5 \mathrm{~g} / 1 \mathrm{KH}_{2} \mathrm{PO}_{4}, 0.2 \mathrm{~g} / 1 \mathrm{MgSO}_{4} \cdot 7 \mathrm{H}_{2} \mathrm{O}, 0.1 \mathrm{~g} / 1 \mathrm{NaCl}, 3.0 \mathrm{~g} / 1 \mathrm{CaCO}_{3}, 17$ $\mathrm{g} / \mathrm{l}$ agar and $100 \mathrm{ml}$ yeast water (pH 6.7) (Tepper et al., 1987). Inoculated plates were incubated at $27^{\circ} \mathrm{C}$ and observed daily for 4 days. Single colonies that resembled root nodule bacteria (slightly raised, opaque and entire) were restreaked on half Fred agar plates.

\section{Identification and physiological characters of cultures}

Strains were identified microscopically, stained by the Gram method, cultivated in meat-peptone agar, milk with neutral red and by keto-lactic test (Tepper $\boldsymbol{e t}$ al., 1987; Holt et al,. 1997).

For the analysis of ability to utilize oxygen, isolated cultures were grown in Fred medium at $27^{\circ} \mathrm{C}$ for seven days. Bacteria were injected into the bottom of testtubes with Fred medium (Tepper et al., 1987).

To test the ability of isolates to form gas during the growing process, cultures were grown in Fred medium at $27^{\circ} \mathrm{C}$ for seven days. Bacteria were injected into the medium thickness of the test-tubes (Tepper et al., 1987).

For the analysis of salt tolerance, isolates were cultivated at $27^{\circ} \mathrm{C}$ under aerobic conditions in liquid modified Fred medium containing $2 \%$ (w/v) $\mathrm{NaCl}$ (Holt $\boldsymbol{e t}$ al., 1997).

The ability of isolates to grow at $\mathrm{pH} 4.0,4.5,5.0,5.5,6.0,6.5,7.0,7.5,8.0,8.5$ was tested in modified liquid Fred medium containing $10 \mathrm{~g} / 1$ mannitol, $0.5 \mathrm{~g} / \mathrm{l}$ $\mathrm{K}_{2} \mathrm{HPO}_{4}, 0.2 \mathrm{~g} / 1 \mathrm{MgSO}_{4} 7 \mathrm{H}_{2} \mathrm{O}, 0.1 \mathrm{~g} / \mathrm{l} \mathrm{NaCl}, 3.0 \mathrm{~g} / \mathrm{l}$ calcium gluconate and 100 $\mathrm{ml}$ yeast water $(\mathrm{pH}$ 6.7) $\mathrm{pH}$ of the medium after autoclaving was 5.0 and then was adjusted using $1 \mathrm{M} \mathrm{HCl}$ or $1 \mathrm{M} \mathrm{KOH}$. Bacteria were grown at $27^{\circ} \mathrm{C}$ under aerobic conditions in modified Fred medium ( $\mathrm{pH}$ 6.7). After $96 \mathrm{~h}$ of growth (stationary phase culture), $0.05 \mathrm{ml}$ of the culture was transferred into $50 \mathrm{ml}$ aliquots of modified Fred medium at different $\mathrm{pH}$ values and cultivated in the same way. Bacterial growth was monitored by measuring optical density of the culture at $600 \mathrm{~nm}$ after $96 \mathrm{~h}$. 
To investigate the ability of microorganisms to utilize different carbon sources, bacteria grown for $96 \mathrm{~h}$ at $27^{\circ} \mathrm{C}$ under aerobic conditions in modified Fred medium ( $\mathrm{pH}$ 6.7) were transferred into Giss medium with Andred reagent $(\mathrm{pH}$ 7.0) containing $10 \mathrm{~g} / \mathrm{l}$ peptone, $5.0 \mathrm{~g} / \mathrm{l} \mathrm{NaCl}, 10 \mathrm{ml}$ Andred reagent and $10 \mathrm{~g} / \mathrm{l}$ of one of the following carbon sources: glucose, sucrose, fructose, lactose, maltose or mannitol (Holt et al., 1997). The samples were then cultivated during $96 \mathrm{~h}$ Growth curves of nodule bacteria strains were tested in Fred medium (pH 6.7) at $27^{\circ} \mathrm{C}$ under aerobic conditions. Optical density was assayed spectrophotometrically at $600 \mathrm{~nm}$ over eight days with one day intervals.

\section{Bacterial strains and chemicals}

Two isolates of nodule bacteria from the pea plants of Ivano-Frankivsk district were used in this study. Efficient Rhizobium leguminosarum 245a strain from the Collection of Institute of Microbiology and Virology named after D.K Zabolotnyj was used as a reference strain. All chemicals were obtained from Reachim (USSR), Reanal (Hungary), Sigma (USA) or from local sources; the chemicals were of the highest purity available.

\section{Chemotaxic assay}

The chemotaxic activity of the strains was investigated on plates with semi-fluid medium ( $\mathrm{pH}$ 6.7) containing $0.5 \mathrm{~g} / 1 \mathrm{~K}_{2} \mathrm{HPO}_{4}, 0.2 \mathrm{~g} / 1 \mathrm{MgSO}_{4} \cdot 7 \mathrm{H}_{2} \mathrm{O}, 0.1 \mathrm{~g} / \mathrm{l} \mathrm{NaCl}$ $2.0 \mathrm{~g} / 1$ calcium gluconate, and $5.0 \mathrm{~g} / \mathrm{l}$ agar. Bacteria were grown at $27^{\circ} \mathrm{C}$ under aerobic conditions in modified Fred medium ( $\mathrm{pH}$ 6.7). For experiments we used bacteria at concentrations $\sim 10^{8}$ cells $/ \mathrm{ml}$. After $96 \mathrm{~h}$ of growth, $20 \mu \mathrm{l}$ of the culture was transferred at the center of plates with semi-fluid medium containing $10 \mathrm{mM}$ attractants and incubated for seven days. The following organic compounds were tested: carbohydrates - glucose, mannitol, sucrose; organic acids - ascorbic citric, malic, pyruvic, tartaric, succinic; amino acids - alanine, aspartic acid, arginine, valine, histidine, glycine, glutamic acid, leucine, lysine, methionine, serine, tyrosine, phenylalanine, and cysteine. Organic compounds were not added to the control group. The chemotaxis of bacteria was estimated by the cell migration to the plate edges measuring the diameter of formed chemotaxic zone (d, mm) (Zhulin and Ignatov, 1986; Kyrychenko, 2005).

\section{Plant material and growth conditions}

The field experiments were carried out in the dendrological park "Dryzhba" of Vasyl Stefanyk Precarpathian National University during May-August of 2007 2008 and 2009 years. Nodule bacteria were cultivated at $27^{\circ} \mathrm{C}$ under aerobic conditions in modified Fred medium ( $\mathrm{pH}$ 6.7). Pea seeds were surface-sterilized in $96 \%$ ethanol for five minutes and "Bilyzna" bleach for $30 \mathrm{~min}$. Then the seeds were washed ten times with sterilized distilled water. Pea seeds of the cultivar "Alpha" were inoculated with nodule bacteria strains for one hour. The contro group of seeds was soaked in distilled water. The seeds planted on plots (in three replications) of $3 \mathrm{~m}^{2}$ area. Each plot consisted of six ranks per six plants each. Plants were harvested for analysis at the stages of 4-5 leaves, budding and flowering. All plants from one rank were harvested for analysis at appropriate stage. In the harvested plants length and mass, number and mass of nodules, concentrations of pigments and starch were measured. Pea seeds were harvested at full ripeness stage and their mass was determined.

\section{Pigment and starch measurements}

For pigment extraction, leaves were homogenized with ice-cold $96 \%$ ethano $(1 / 10, w / v)$ in the presence of $\mathrm{CaCO}_{3}$ to avoid pheophytinization. The homogenates were centrifuged at $8,000 \times \mathrm{g}$ for $10 \mathrm{~min}\left(4^{\circ} \mathrm{C}\right)$, supernatants were collected and the pellets were re-extracted three-times with $1 \mathrm{ml}$ ice-cold $96 \%$ ethanol and combined with the original supernatant. The concentration of pigments was then measured spectrophotometrically in the combined extracts. Specific absorption coefficients for chlorophyll $a$, chlorophyll $b$, total chlorophyl and total carotenoids were used (Lichtenthaler, 1987). A molecular mass of 570 for carotenoids was used for calculation. Anthocyanin content was determined after extract acidification with concentrated $\mathrm{HCl}$ to a final concentration of $1 \%$. Anthocyanin concentration was assayed spectrophotometrically at $530 \mathrm{~nm}$ using an absorption coefficient of $30 \mathrm{mM}^{-1} \mathrm{~cm}^{-1}$ (Gitelson et al., 2001). Starch concentration was measured spectrophotometrically at $600 \mathrm{~nm}$ in the pellets that remained after pigment extraction. This method is based on the ability of starch to form a starch-iodine complex with $\mathrm{KJ}$ (Chang, 1979). Water-soluble potato starch was used to produce the calibration graph. Experimental data are expressed as the mean \pm standard error of the mean (SEM), and statistical testing used the Student's $t$-test.

\section{RESULTS AND DISCUSSION}

\section{Isolation and identification of bacteria}

Pea plants were collected from different soils in Tysmenyckyj and Tlumackij regions of Ivano-Frankivsk district. Sod-podzol soils prevail in Tysmenyckyj region and they are characterized by minor humus content $(2.8-3.0 \%)$, soil $\mathrm{pH}$ 5.6 and low content of nitrogen, organic and mineral compounds (Yakyimivand Zaklinski, 2005). In the Tlumackij region black soils prevail, which have high humus level (3.6-4.2\%), pH 5.9 and high fertility (Yakyimiv and Zaklinski, 2005).

Two pea nodule bacteria strains were selected from 12 isolates, and designated as RRL8 and RRL9. These selected strains were able to form rosy nodules a plant roots in sterile conditions (not shown). Bacterial cultures were characterized by fast growth. After 3-4 days of incubation on solidified Fred medium they formed round mucus protuberant large $(3-5 \mathrm{~mm})$ semilucent colonies with a mat tint. The surface of colonies was smooth, with homogeneous structure. Under microscope, cells looked like shallow mobile sticks. Bacteria were mostly small, very polymorphic and Gram-negative. On the meat-peptone agar nodule bacteria did not form colonies which corresponded to literature data for Rhizobium bacteria (Tepper et al,. 1987; Holt et al., 1997; Patyka et al,. 2003).

It is known that nodule bacteria can hydrolyze casein and increase milk $\mathrm{pH}$ (Tepper et al,. 1987). After cultivation for 10-14 days in liquid milk with an indicator neutral red we found, that these bacteria formed a whey area reflecting hydrolysis of milk casein. The bacterial cultures of RRL8 and RRL9 strains also increased milk pH from 7.0 to 7.8 and 8.1, respectively, after 12 days of growth The $\mathrm{pH}$ value was also confirmed by the change in color of the neutral red indicator from pink to yellow.

In order to differentiate Rhizobium bacteria from Agrobacterium bacteria, a ketolactic test was used (Tepper $\boldsymbol{e t} \boldsymbol{a l}$,. 1987). The test was negative for the RRL8 and RRL9 cultures, confirming that our bacteria belonged to the Rhizobium genus.

After injection into the bottom of tubes with Fred medium (Tepper et al,. 1987), bacterial cultures grew in the top part of the medium, demonstrating that they are aerobes. Furthermore, these nodule bacteria did not form gas during the growth process and did not grow in Fred medium containing $2 \% \mathrm{NaCl}$. Our findings corresponded well with the literature on Rhizobium bacteria (Tepper et al,. 1987; Holt et al., 1997; Patyka et al., 2003).

The $\mathrm{pH}$ optimum for growth by nodule bacteria of the RRL8 strain was from 4.0 to 7.0 and at higher $\mathrm{pH}$ values $(7.5,8.0,8.5)$ they grew slower (not shown). The RRL9 strain had a broader $\mathrm{pH}$ optimum from 4.0 to 8.0 (not shown).

It is known that the peculiarities of nodule bacteria metabolism are determined to a large extent by the carbon source available to them (Krutylo et al., 2008) Hence, bacterial strains were tested for their ability to grow with different carbon sources in Giss medium with Andred indicator and 1\% w/v of each carbohydrate tested (Holt et al., 1997). Carbohydrate splitting and acid formation, which took place during bacteria growth, were determined by the color of the Andred reagent and bacterial growth intensity by the change in light scattering. Bacterium RRL8 and RRL9 strains utilized all carbohydrates tested, but growth intensity of the culture was different (not shown). Growth of nodule bacteria also changed the color of the Anred indicator from yellow to pink which means that the culture medium was acidified. Bacteria readily utilized glucose, sucrose, fructose and maltose, but media with lactose and mannitol were used only moderately.

\section{Growth curve}

The time-course of RRL8 and RRL9 nodule bacteria growth is shown at Fig. 1 Bacteria of the RRL8 strain passed through all normal growth

phases over eight days. However, the RRL9 strain showed no lag-phase. RRL9 bacteria also grew slowly in the medium used and the optical density of the bacterial culture decreased on the $8^{\text {th }}$ cultivation day.

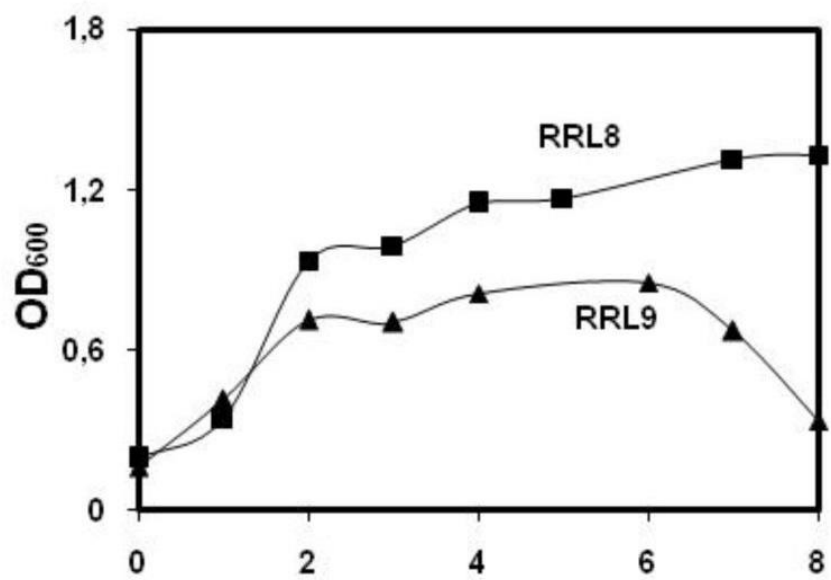

Time period, day

Figure 1 Growth curves of nodule bacteria strains in liquid Fred medium $(\mathrm{pH}$ 6.7 ) at $27^{\circ} \mathrm{C}$ under aerobic conditions over 8 days. Data of a typical experiment are shown 
It is known that fast-growing nodule bacteria, in particular R. leguminosarum bv. viciae, show an exponential phase over the first days of their growth (Koleshko, 1981). Our findings were in a good agreement with the literature, because the cultures reached the middle of the exponential phase of growth in 2 days (Koleshko, 1981). Stationary phase of growth were reached on days 3-4.

\section{Chemotaxic activity}

The chemotaxis of bacteria to plant root exudate plays an important role in symbiotic cooperation between plants and nodule bacteria (Kyrychenko, 2005; Morgun and Kots, 2008). Many root exudates are chemoattractants for nodule bacteria (Yost, 2003; Bais et al, 2006). Rhizobia show positive chemotaxis to plant root exudates and move to certain places on the legume root (Yost, 2003; Walker, 2003). Amino acids, carbohydrates, and organic acids are the most important components of root exudates that act as chemoattractants for microorganisms (Rhijn and Vanderleyden., 1995; Kyrychenko, 2005). Data presented in Table 1 show that bacteria of RRL8, RRL9 strains and $R$. leguminosarum bv. viciae 245 a had a positive chemotactic reaction to most of the organic substances tested.

Sucrose was the most efficient attractant among carbohydrates. Glucose was also an active attractant for RRL8 and 245a strains as was mannitol for RRL9. Among organic acids, citric acid was the most effective attractant for the RRL8, wheras for RRL9 it was pyruvic acid and for 245a it was tartaric acid. Diameters of chemotaxic zones for effective chemoattractants were up to 1.5-, 1.8-, 1.9-fold larger compared to control values, respectively.

Amino acids are the most studied chemical effectors for microorganisms. Each species have typical attractants and repellents among the amino acids (Zhulin and Ignatov, 1986). It was found that germinating peas excrete 23 amino acids (Kyrychenko, 2002). The data in Table 1 show that aspartic acid, glycine, serine and valine were the most active attractants among the amino acids tested for all three strains. The diameter of the chemotaxic zones was 1.7-2.4-fold larger than for corresponding controls. Alanine and lysine were also efficient attractants for RRL9 and 245a strains.

Table 1 Diameters of chemotaxic zones $(\mathrm{mm})$ formed by Rhizobium leguminosarum bv. viciae
Organic compounds

\begin{tabular}{|c|c|c|c|c|}
\hline & & RRL8 & RRL9 & $245 a$ \\
\hline \multirow{4}{*}{ 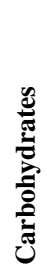 } & Control & $13.8 \pm 0.4$ & $15.8 \pm 1.2$ & $14.3 \pm 0.5$ \\
\hline & Glucose & $19.5 \pm 0.5^{*}$ & $19.0 \pm 1.2$ & $24.8 \pm 1.3 *$ \\
\hline & Mannitol & $17.3 \pm 0.3^{*}$ & $23.0 \pm 0.8^{*}$ & $16.9 \pm 2.8$ \\
\hline & Sucrose & $19.0 \pm 1.3^{*}$ & $26.5 \pm 1.6^{*}$ & $25.2 \pm 2.8^{*}$ \\
\hline \multirow{6}{*}{ 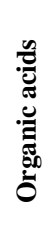 } & Ascorbic acid & $16.7 \pm 0.3 *$ & $16.4 \pm 1.0$ & $24.5 \pm 0.6^{*}$ \\
\hline & Citric acid & $21.0 \pm 0.9 *$ & $25.0 \pm 0.2 *$ & $18.9 \pm 1.3 *$ \\
\hline & Malic acid & $17.7 \pm 0.7 *$ & $22.7 \pm 0.9 *$ & $24.3 \pm 1.5^{*}$ \\
\hline & Pyruvic acid & $18.0 \pm 0.4^{*}$ & $28.5 \pm 1.0^{*}$ & $21.5 \pm 1.5^{*}$ \\
\hline & Succinic acid & $20.0 \pm 0.2$ & $25.0 \pm 0.2 *$ & $20.6 \pm 0.4^{*}$ \\
\hline & Tartaric acid & $16.8 \pm 0.5^{*}$ & $22.3 \pm 1.5^{*}$ & $26.9 \pm 0.8^{*}$ \\
\hline \multirow{14}{*}{ 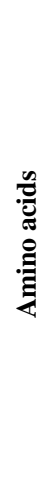 } & Alanine & $21.5 \pm 0.3^{*}$ & $31.3 \pm 2.1^{*}$ & $29.8 \pm 2.6^{*}$ \\
\hline & Aspartic acid & $24.0 \pm 0.9^{*}$ & $27.5 \pm 1.0 *$ & $28.3 \pm 3.1^{*}$ \\
\hline & Arginine & $19.5 \pm 0.7 *$ & $16.5 \pm 0.7$ & $25.5 \pm 1.8^{*}$ \\
\hline & Cysteine & $21.8 \pm 0.6^{*}$ & $19.4 \pm 1.9$ & $23.0 \pm 0.6^{*}$ \\
\hline & Histidine & $18.3 \pm 1.0^{*}$ & $23.0 \pm 1.5^{*}$ & $26.8 \pm 2.1 *$ \\
\hline & Glycine & $25.3 \pm 1.1^{*}$ & $37.3 \pm 1.1^{*}$ & $27.2 \pm 1.1 *$ \\
\hline & Glutamic acid & $20.7 \pm 0.9 *$ & $16.6 \pm 1.0$ & $25.0 \pm 3.5^{*}$ \\
\hline & Leucine & $21.0 \pm 1.0^{*}$ & $22.3 \pm 1.1^{*}$ & $25.9 \pm 2.9 *$ \\
\hline & Lysine & $19.5 \pm 1.2 *$ & $30.5 \pm 1.7 *$ & $27.4 \pm 2.0^{*}$ \\
\hline & Methionine & $21.3 \pm 0.3^{*}$ & $25.8 \pm 1.8^{*}$ & $16.5 \pm 1.3$ \\
\hline & Serine & $22.8 \pm 2.5^{*}$ & $27.8 \pm 1.8^{*}$ & $30.3 \pm 0.9 *$ \\
\hline & Tyrosine & $25.0 \pm 0.6^{*}$ & $17.8 \pm 0.9$ & $24.6 \pm 1.5^{*}$ \\
\hline & Phenylalanine & $22.5 \pm 1.0^{*}$ & $18.3 \pm 0.9$ & $28.0 \pm 1.5^{*}$ \\
\hline & Valine & $24.3 \pm 1.0^{*}$ & $26.8 \pm 2.5^{*}$ & $29.4 \pm 2.0 *$ \\
\hline
\end{tabular}

values with $\mathrm{P}<0.05$
Histidine, leucine and cysteine had moderate chemotaxic effects with all bacterial strains. For Azospirillum it was shown that all $L$-amino acids in wheat root exudate were efficient attractants for these bacteria, whereas among $D$-amino acids with bacteria only leucine, serine and glutamic acid were not active (Zhulin and Ignatov, 1986). Bacillus subtilis and Rhizobium meliloti showed positive chemotaxis to all $L$-amino acids (Kyrychenko, 2005; Zhulin and Ignatov, 1986). Alanine, tyrosine and tartaric acid are effective attractants for Bradyrhizobium lupini (Kyrychenko, 2005). A significant role of aspartic and glutamic acids as the attractants for pea nodule bacteria was shown (Kyrychenko, 2002) whereas our study showed positive chemotaxis to most of the amino acids tested, including aspartic and glutamic acids. Alanine, glycine, serine and valine were strong attractants, whereas chemotaxic activity to some amino acids was selective, in particular, to arginine, cysteine, tyrosine and phenylalanine. Hence, in the present work, pea nodule bacteria strains differed in their chemotaxic activity to carbohydrates, organic acids and amino acids, indicating strain specificity. These findings are in a good agreement with results from other laboratories on the specificity of lupine nodule bacteria to organic compounds (Kyrychenko, 2005) and Azospirilla (Kyrychenko, 2002).

\section{Morphometric plant analysis}

Field experiments were conducted during May-August in 2007, 2008 and 2009 years. Pea plants were harvested at the stages of 4-5 leaves, budding and flowering. Plant length and mass, number and mass of nodules, concentration of pigments and starch as well as mass of seeds were investigated in these experiments. Data presented in Fig. 2A show that at the stage of 4-5 leaves shoot length of the plants inoculated with the RRL9 strain was $14 \%$ greater compared to those inoculated with the 245a strain. At the budding stage, the plants treated with RRL8 and RRL9 strains showed $13 \%$ and $11 \%$ greater shoot length compared to control plants, respectively. Furthermore, the pea plants treated with the local bacterial strains also outperformed those inoculated with the $245 \mathrm{a}$ strain at the budding stage, with the length of shoots being $14 \%$ and $11 \%$ higher, respectively. At the flowering stage, plants inoculated with local RRL8 and RRL9 strains showed lengths of shoots that were still higher by 23 and $16 \%$, respectively, compared to plants inoculated with the 245 a strain although shoot lengths did not differ among control, RRL8 and RRL9 groups. Thus, the data show a significant advantage of local nodule bacterial strains in increasing pea growth at both budding and flowering stages.

Treatment with three nodule bacterial strains had smaller effect on pea root growth than on the shoots. Plants treated with the RRL8 strain showed 12\% longer roots at the 4-5 leaves stage as compared with both control group and the 245a strain treated plants (Fig. 2B). Plants treated with RRL9 nodule bacteria also showed $8 \%$ longer roots compared with $245 \mathrm{a}$ strain ones. The inoculation of pea seeds with local strains and the standard 245a strain did not affect the length of pea roots at the budding stage. However, at the flowering stage, plants inoculated with RRL9 and 245a strains showed roots that were, $18 \%$ and $15 \%$ shorter, respectively, than controls. 

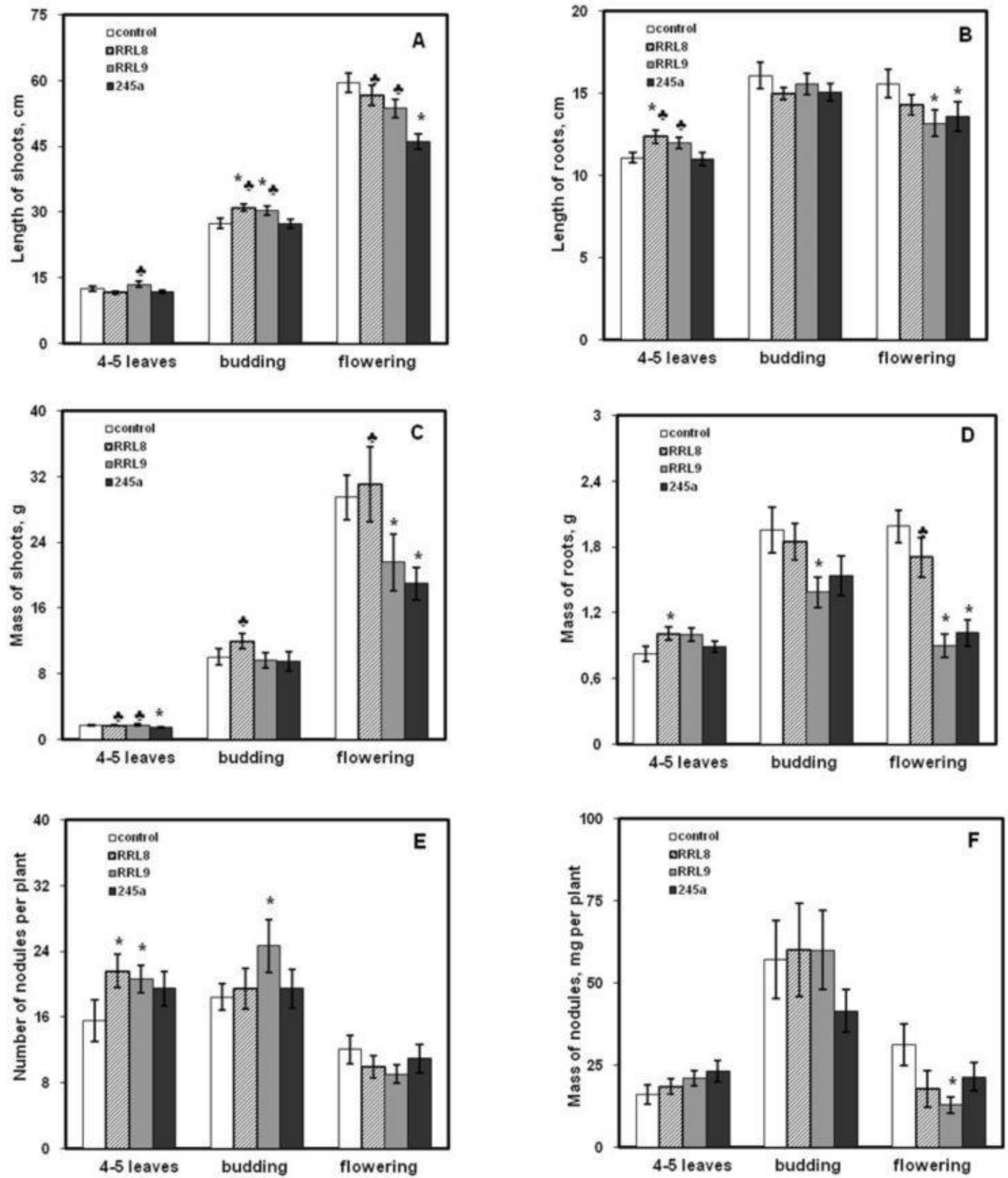

Figure 2 Length $(\mathrm{cm})$ of shoots $(\mathrm{A})$, roots $(\mathrm{B})$, wet mass $(\mathrm{g})$ of shoots $(\mathrm{C})$ and roots $(\mathrm{D})$ and number of nodules $(\mathrm{E})$ and nodule mass $(\mathrm{F})$ in pea plants inoculated with nodule bacteria. Data are mean \pm SEM $(n=3)$. *Significantly different from respective control values with $\mathrm{P}<0.05$, *different from the respective 245 a strain group with $\mathrm{P}<0.05$

It is known that the mass of plants is one of the most important criteria in the analysis of symbiosis efficacy in leguminous plants and nodule bacteria (Antipchuk et al., 2002). At the stage of 4-5 leaves, the mass of shoots in plants inoculated with local strains was higher by $14 \%$ and $17 \%$, respectively, compared to plants inoculated with the standard 245a strain (Fig. 2C), but did not differ from uninoculated controls. At the budding stage, plants inoculated with the RRL8 strain also showed a greater mass of shoots, $26 \%$ higher as compared with plants inoculated with the 245a strain. In the flowering plants the RRL8 treated ones showed a mass of shoots that was similar to controls, but $64 \%$ higher than the mass of shoots from plants inoculated with the $245 \mathrm{a}$ strain. Indeed, plants inoculated with both the RRL9 and 245a strains showed a significantly lower mass of shoots by $37 \%$ and $55 \%$, respectively, compared with controls. Furthermore, at the flowering stage, when the requirement of plants for nitrogen is enhanced due to the formation of reproductive organs (Krugova, 1995), we observed the most extensive increase in pea shoot mass.
At the initial stage of pea plant ontogenesis, plants inoculated with the RRL8 strain showed a mass of roots $22 \%$ higher than respective control ones (Fig. 2D). At the budding stage, plants inoculated with RRL8 showed a root mass similar to controls, but those inoculated with RRL9 strain had a root mass that was $41 \%$ lower compared to control plants; the 245a inoculated plants also showed a trend for reduced root mass. At flowering stage, RRL8 and control plants showed a high root mass, but those treated with RRL9 and 245a strains showed a root mass that was only about half of the control value. The RRL8 treated plants showed a mass of roots that was $68 \%$ higher compared to those inoculated with $245 \mathrm{a}$ strain. The number of root nodules and their mass is another criterion for the estimation of efficacy cooperation between micro- and macrosymbionts (Antipchuk et al, 2002). The results of our experiments showed that at the stage of 4-5 leaves the number of nodules, formed by RRL8 and RRL9 bacterial strains, was 1.4-fold and 1.3-fold higher than in control plants, respectively (Fig. 2E). At the budding stage, plants inoculated with the RRL9 strain showed a 1.3-fold higher number of 
nodules than in controls. However, the treatment of pea seeds by local and standard strains did not affect the number of nodules on roots at the flowering stage. Maximum nodule number is usually observed at the flowering stage of plants (Lukashevich and Shloma, 2005). However, in our research, the maximum number of nodules was at the budding stage. Previous studies by Krugova et al. (1994) also indicated that in pea plants inoculated with $R$ leguminosarum 250a that nodule development and maximum mass also occurred at the early stages of plant vegetation. The flowering stage in our experiments was accompanied by nodule necrosis and a decrease in nodule number on roots in comparison to the previous growth stages of pea plants. A similar effect was described by Lukaschewich et al. (2005) in a study of the influence of bacteria and nitric nutrition of pea on symbiotic apparatus formation. That is probably connected with low soil humidity which results in disappearance of nodules formed earlier. At the late stages of plant ontogenesis, the development of roots is halted and plant degradation processes are activated (Tarchevsky, 1996). At the 4-5 leaves and budding stages, the mass of nodules did not differ from the contro for any of the treatment groups (Fig. 2F), whereas at the flowering stage all treatment groups showed a trend to reduced nodule mass as compared with controls with plants inoculated with the RRL9 strain showing significantly lower nodule mass in comparison to control.

\section{Concentrations of pigments and starch}

Leguminous plants demonstrate cooperation between the processes of photosynthesis and nitrogen fixation (Patyka et al., 2003). The concentrations of pigments, particularly chlorophylls and carotenoids, depend on the nitrogen supply to plants (Okhrimenko, 2001). Plants provide assimilants and energy sources for nodule bacteria, whereas the latter provide nitrogen compounds for plants (Okhrimenko, 2001; Ferguson et al., 2005). To study the efficiency of the Rhizobium strains in providing nitrogen to the plants, the concentrations of the main photosynthetic pigments, chlorophylls and carotenoids, as well as the vacuolar pigment anthocyanin, were measured. The treatment of pea seeds with local Rhizobium strains RRL8 and RRL9, and the standard strain $R$ leguminosarum 245a had very few effects at the 4-5 leaves stage as compared with control plants (Table 2); a small increase in chlorophyll $b$ occurred in RRL9 treated plants and a small decrease in carotenoid content was seen in RRL8 plants. RRL8 plants also showed small reductions in chlorophyll $a$, carotenoids and anthocyanins as compared with the 245a treated plants.

At the budding stage, in plants inoculated with the RRL9 strain the concentration of most pigments was higher by $11 \%$ compared to controls and by $12 \%$ compared to plants inoculated with 245 a strain. In flowering plants, inoculated with the RRL8 strain, the concentration of total chlorophyll $(a+b)$ was $14 \%$ higher than that in both control and plants inoculated with the standard 245a strain. Finally, as has been reported previously for chlorophyll $a$ in pea shoots (Okhrimenko, 2001), the concentration of chlorophyll $a$ generally increased over the three growth stages to get be maximum at the flowering stage. Chlorophyll $b$ and total chlorophyll also increased between the 4-5 leaves and budding stages and then remained stable during flowering.

Table 2 The concentrations of chlorophylls ( $\mu \mathrm{mol} / \mathrm{g}$ dry wt), carotenoids ( $\mu \mathrm{mol} / \mathrm{g}$ dry wt) and anthocyanins ( $\mu$ mol/g dry wt) in the pea leaves from plants inoculated with nodule bacteria

\begin{tabular}{|c|c|c|c|c|c|}
\hline & Pigments & Control & RRL8 & RRL9 & $245 a$ \\
\hline \multirow{6}{*}{ 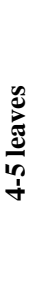 } & Chlorophyll $a$ & $1.32 \pm 0.05$ & $1.23 \pm 0.04^{\star}$ & $1.32 \pm 0.05$ & $1.33 \pm 0.03$ \\
\hline & Chlorophyll $b$ & $0.37 \pm 0.01$ & $0.37 \pm 0.03$ & $0.43 \pm 0.04^{*}$ & $0.38 \pm 0.02$ \\
\hline & Total chlorophyll & $1.69 \pm 0.06$ & $1.60 \pm 0.06$ & $1.75 \pm 0.05$ & $1.64 \pm 0.06$ \\
\hline & Chl $a /$ Chl $b$ ratio & 3.57 & 3.32 & 3.07 & 3.50 \\
\hline & Carotenoids & $0.70 \pm 0.03$ & $0.63 \pm 0.02 * *$ & $0.70 \pm 0.03$ & $0.70 \pm 0.02$ \\
\hline & Anthocyanins & $0.66 \pm 0.03$ & $0.64 \pm 0.03^{\star}$ & $0.68 \pm 0.03$ & $0.69 \pm 0.02$ \\
\hline \multirow{6}{*}{ 串 } & Chlorophyll $a$ & $1.48 \pm 0.03$ & $1.55 \pm 0.05$ & $1.64 \pm 0.03 *$ & $1.47 \pm 0.04$ \\
\hline & Chlorophyll $b$ & $0.52 \pm 0.04$ & $0.52 \pm 0.04$ & $0.49 \pm 0.03$ & $0.51 \pm 0.03$ \\
\hline & Total chlorophyll & $2.00 \pm 0.06$ & $2.03 \pm 0.07$ & $2.21 \pm 0.08^{* *}$ & $1.98 \pm 0.07$ \\
\hline & Chl $a /$ Chl $b$ ratio & 2.85 & 2.98 & 3.35 & 2.88 \\
\hline & Carotenoids & $0.79 \pm 0.03$ & $0.83 \pm 0.07$ & $0.96 \pm 0.09^{* \star}$ & $0.78 \pm 0.05$ \\
\hline & Anthocyanins & $0.68 \pm 0.03$ & $0.69 \pm 0.04$ & $0.73 \pm 0.03^{*}$ & $0.66 \pm 0.04$ \\
\hline \multirow{6}{*}{$\frac{90}{3}$} & Chlorophyll $a$ & $1.57 \pm 0.04$ & $1.70 \pm 0.05$ & $1.49 \pm 0.04$ & $1.61 \pm 0.05$ \\
\hline & Chlorophyll $b$ & $0.46 \pm 0.03$ & $0.62 \pm 0.05^{* *}$ & $0.52 \pm 0.04$ & $0.46 \pm 0.04$ \\
\hline & Total chlorophyll & $2.03 \pm 0.04$ & $2.32 \pm 0.09^{* *}$ & $2.00 \pm 0.06$ & $2.07 \pm 0.07$ \\
\hline & Chl $a / \mathrm{Chl} b$ ratio & 3.41 & 2.74 & 2.87 & 3.50 \\
\hline & Carotenoids & $0.76 \pm 0.02$ & $0.70 \pm 0.04$ & $0.65 \pm 0.04$ & $0.78 \pm 0.04$ \\
\hline & Anthocyanins & $0.75 \pm 0.04$ & $0.79 \pm 0.04$ & $0.68 \pm 0.04^{\star}$ & $0.77 \pm 0.05$ \\
\hline
\end{tabular}

Data are means for independent samples from three different years \pm SEM $(n=3)$. *Significantly different from respective control values with $\mathrm{P}<0.05$, ${ }^{*}$ from the respective 245 a strain group with $\mathrm{P}<0.05$

The treatment of pea seeds by local and standard strains did not affect the chlorophyll $b$ concentration in pea leaves at the 4-5 leaves and budding stages (Table 2). At the flowering stage in plants inoculated with RRL8 strain the concentration of this pigment was $35 \%$ higher relative to plants inoculated with the 245 a strain.

In control plants, the maximum chlorophyll $\mathrm{a} / \mathrm{b}$ ratio was at flowering stage (Table 2). Similar results were reported by Okhrimenko (2001). In plants inoculated with the RRL8 strain the maximum chlorophyll a/b ratio was at the 45 leaves stage, whereas with RRL9 it was at the budding stage.

In addition to chlorophylls, chloroplasts also contain carotenoids (Kato et al., 2004). They function as additional pigments and are active components of the chloroplast photosynthetic system (Okhrimenko, 2001; Kato et al., 2004). The concentration of carotenoids in plants inoculated with the RRL8 strain was lower at the 4-5 leaves stage as compared to controls and plants inoculated with 245 a strain bacteria (Table 2). At the budding stage, plants inoculated with the RRL9 strain showed $22 \%$ higher level of carotenoids that control group and by $23 \%$ higher compared to plants inoculated with the $245 \mathrm{a}$ strain. Inoculation of pea seeds by local and standard strains did not affect the carotenoid concentration at flowering stage.
Vacuolar pigments anthocyanins play an important role in plant life, because they are additional pigments and have a sunscreen and other protective functions. An increase in anthocyanin content was demonstrated as an adaptive response of plants to diverse environmental conditions, nitrogen and phosphorus deficiency, and bacterial and fungal infections (Gould, 2004; Munne-Bosch et al., 2006; Rossesetto et al., 2007). Our experimental data show that concentration of anthocyanins in pea plants inoculated by nodule bacteria did not differ from controls over the whole plant ontogenesis (Table 2). At the same time, the concentration of anthocyanins in plants inoculated with RRL8 strain at the 4-5 leaves stage was lowest in comparison with those inoculated with 245 a strain plants. At the budding stage, plants inoculated with RRL9 strain showed a concentration of these pigments that was $11 \%$ higher compared to those inoculated with the 245a strain. At flowering stage, plants inoculated with the RRL9 strain showed a concentration of anthocyanins that was $13 \%$ lower than in those treated with the standard 245a strain.

Photosynthesis provides energy sources for nitrogen fixation. It is known that the efficacy of nodule bacteria symbiosis depends on the flux of photoassimilated compounds to nodules on plant roots (Voisin et al., 2003; Mandrovskaya et al., 1995). Photosynthetic products which are formed in leaves are the main energy source for nodule growth, bacteroid respiration and nitrogen fixation (Patyka et 
al., 2003). A supply of photoassimilated compounds to nodules is a main factor that regulates the process of atmospheric nitrogen fixation in infected leguminous plants (Mandrovskaya et al., 1995). At the 4-5 leaves stage, the concentration of starch in plants inoculated with RRL8 and 245a strains was 1.4-fold lower compared to controls, whereas RRL9 is equal to control (Fig. 3).

This effect can be associated with the extensive nodule formation at initial stages of pea plant growth, where the resources are directed to. Furthermore, in plants inoculated with the RRL9 strain, the starch concentration was 1.4-fold higher compared to plants inoculated with 245 a bacteria. At the flowering stage, in plants inoculated with the RRL9 strain the starch concentration was 1.4-fold lower than that in controls or plants inoculated with the 245a strain.

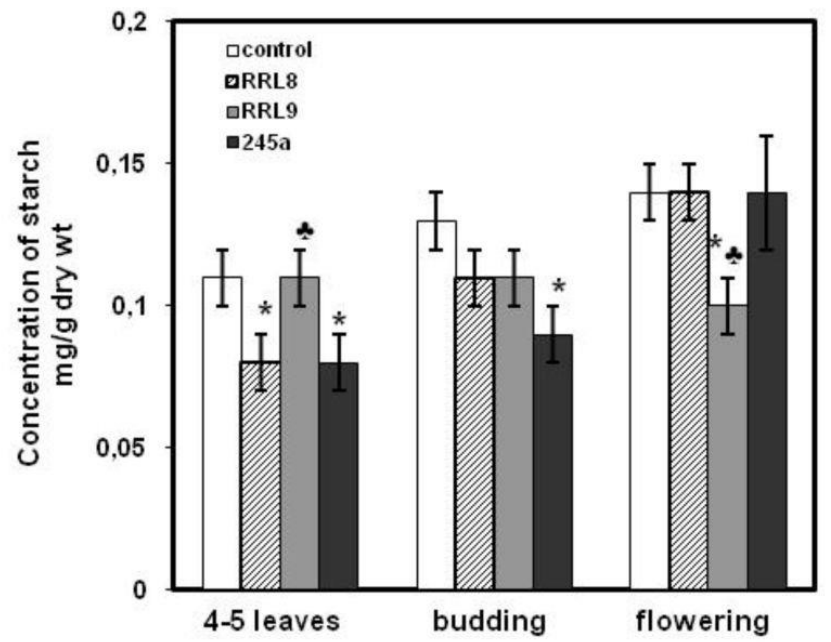

Figure 3 The starch concentration (mg/g dry wt) in pea plants inoculated with nodule bacteria. Data are mean $\pm \operatorname{SEM}(n=3)$. *Significantly different from respective control values with $\mathrm{P}<0.05$, *different from the respective 245 a strain group with $\mathrm{P}<0.05$

\section{Grain crop}

The efficacy of legume-rhizobium symbiosis under conditions of treatment with nodule bacteria strains was estimated as the pea crop capacity. The maximum pea grain crop was observed in plants treated with bacteria of the RRL8 strain; the mass of seeds per plant was $19 \%$ higher than in control plants (Table 3 ).

Table 3 Yield of pea plants

\begin{tabular}{lcc}
\hline Strains & $\begin{array}{c}\text { Mass of seeds from one } \\
\text { plant, } \mathbf{g}\end{array}$ & $\begin{array}{c}\text { Seed yield, } \\
\text { quintal/hectare }\end{array}$ \\
\hline Control & $10.8 \pm 0.7$ & 13.0 \\
RRL8 & $12.9 \pm 1.1^{* *}$ & 15.5 \\
RRL9 & $9.43 \pm 0.6$ & 11.3 \\
245a & $8.41 \pm 0.5^{*}$ & 10.1 \\
\hline
\end{tabular}

Data are means for independent samples from three different years \pm SEM $(\mathrm{n}=3)$.*Significantly different from respective control values with $\mathrm{P}<0.05$, *from respective with 245 a strain group with $\mathrm{P}<0.05$

Other researchers showed that inoculation of pea seeds with nodule bacteria increased the harvest of pea by $8.8-15.8 \%$ compared to controls depending on the cultivar of plants and the bacteria strain (Lukashevich and Shloma, 2005). It is known that treatment of seeds of alfalfa, pea, lupin, clover and soybeen with industrial preparations of bacterial strains usually increases the harvest of these cultures for $10-20 \%$ (Kots, 2001). Inoculation of pea seeds with the $R$ leguminosarum 245 a strain under our soil and climatic conditions did not affect the pea crop capacity. Furthermore, in plants inoculated with RRL8 strain the mass of pea grain was $53 \%$ higher than in those inoculated with strain $245 \mathrm{a}$ Hence, the strains isolated in Ivano-Frankivsk district under defined environmental conditions showed maximum efficiency compared with a standard strain. It is known that industrial strains which are used for inoculation compete with indigenous strains that are usually well adapted to local conditions and can more efficiently infect plants than introduced strains (Krugova et al., 1994).

\section{CONCLUSIONS}

It can be conclud that two nodule strains RRL8 and RRL9 differed in their chemotaxic activity to carbohydrates, organic acids and amino acids, indicating strain specificity. The data shows that pea nodule bacteria form effective legumerhizobium symbiosis and enhance the harvest of pea crops with bacterial strains that are native to particular soil and climatic conditions having the greatest effect in increasing crop yield.

Acknowledgements: We are grateful to staff of dendrology park "Dryzhba" of Vassyl Stefanyk Precarpathian National University for the technical assistance with the field experiments, and to J.M. Storey (Carleton University, Ottawa Canada) for English corrections and editorial comments on the manuscript.

\section{REFERENCES}

ANTIPCHUK, A.F., KRASNOBRYZHAYA, E.N., LEONOVA, N.O., TANTSYRENKO, E.V., IUTINSKA, G.O. 2002. Especial features of the formation and function of bean-rhizobial symbiosis under heavy metals pollution. Physiology and Biochemistry Cultural Plants, 34, 63-69. [in Ukrainian]

BAIS, H.P., WEIR, T.L., PERRY, L.G., GILROY, S., VIVANCO, J.M. 2006. The role of root exudates in rhizosphere interactions with plants and other organisms. Annual Review of Plant Biology, 57, 233-266. http://dx.doi.org/10.1146/annurev.arplant.57.032905.105159.

FERGUSON, B.J., ROSS, J.J., REID, J.B. 2005. Nodulation phenotypes of gibberellin and brassinosteroid mutants of pea. Plant Physiology, 138, 23962405. http://dx.doi.org/10.1104/pp. 105. 062414

GAGE, D.J. 2004. Infection and invasion of roots by symbiotic, nitrogen-fixing rhizobia during nodulation of temperate Legumes. Microbiology and Molecular Biology Reviews, 68, 280-300. http://dx.doi.org/10.1128/mmbr.68.2.280 300.2004

CHANG, C.W. 1979. Starch and its component ratio in developing cotton leaves. Plant Physiology, 63, 973-977. http://dx.doi.org/10.1104/pp.63.5.973

GITELSON, A.A., MERZLYAK, M.N., CHIVKUNOVA, O.B. 2001. Optical properties and non-destructive estimation of anthocyanin content in plant leaves. Photochemistry Photobiology, 7, 38-45. http://dx.doi.org/10.1562/0031 8655(2001)074<0038:opaneo>2.0.co;2

GOULD, K.S. 2004. Nature's Swiss army knife: the diverse protective roles of anthocyanins in leaves. Journal of Biomedicine and Biotechnology, 5, 314-320. http://dx.doi.org/10.1155/s1110724304406147

GRESSHOFF, P.M. 2003. Post-genomic insights into plant nodulation symbioses. Genome Biology, 4, 201. http://dx.doi.org/10.1186/gb-2003-4-1-201 HOLT, J., KRIEG N., SNIT P., STALEY J., WILLIAMS S. 1997. Bergey's manual of determinative bacteriology in 2 vol. Vol. 1. Moscow: Myr, $432 \mathrm{p}$. ISBN 5-03-003112-X [in Russian].

KARUNAKARAN, R., RAMACHANDRAN, V.K., SEAMAN, J.C., EAST, A.K., MOUHSINE, B., PRELL, J., SKEFFINGTON, A., POOLE, P.S. 2009. Transcriptomic analysis of Rhizobium leguminosarum biovar viciae in symbiosis with host plants Pisum sativum and Vicia cracca. Journal of Bacteriology, 191, 4002-4014. http://dx.doi.org/10.1128/jb.00165-09

KATO, M., IKOMA, Y., MATSUMOTO, H., SUGIERA, M., HYODO, H. YANO, M. 2004. Accumulation of carotenoids and expression of carotenoid biosynthetic genes during maturation in citrus fruit. Plant Physiology, 134, 824837. http://dx.doi.org/10.1104/pp.103.031104

KOLESHKO, O.I. 1981. Nitrogen-fixing bacteria: physiology of development Minsk: BGU, 111p. [in Russian].

KOTS, S.Ya. 2001. Role of biological nitrogen in increasing the productivity of crops. Physiology and Biochemistry Cultural Plants, 33, 208-215. [in Ukrainian] KRUGOVA, O.V. 1995. The effect of bound nitrogen and rhizobium strain activity on nitrogen metabolism in pea. Physiology and Biochemistry Cultural Plants, 27, 174-175. [in Russian]

KRUGOVA, E.D., OSTAPENKO, D.D., MANDROVSKAYA, N.M. 1994. The sort specify in pea plants at the inoculation by different strains of nodule bacteria Physiology and Biochemistry Cultural Plants, 26, 245-251. [in Russian] KRUTYLO, D.V., NADKERNYCHNA, O.V., KOVALEVSKA, T.M., PATYKA, V.P. 2008. Biological diversity of soybean nodule bacteria in soils of Ukraine. Physiology Biochemistry Cultural Plants, 6, 27-34. [in Ukrainian] KYRYCHENKO, O.V. 2002. Relationships of leguminous plants and nodule bacteria on the level of before-contact interactions when forming nitrogen-fixing systems. Physiology and Biochemistry Cultural Plants, 34, 95-101. [in Russian] KYRYCHENKO, O.V. 2005. Study of chemotaxis of nodule bacteria of lupin to organic substances. Mikrobiologichny Zhurnal, 67, 19-26 [in Russian]

LICHTENTHALER, H.K. 1987. Chlorophylls and carotenoids: pigments of photosynthetic biomembranes. Methods in Enzymology, 148, 350-382. http://dx.doi.org/10.1016/0076-6879(87)48036-1

LUKASHEVICH, N.P., SHLOMA, T.M. 2005. Formation of crop capacity of peas in dependence of nitric feeding in conditions of Vitebsk region. Proceedings of the National Academy of Sciences of Belarus, 2, 43-47. [in Russian]

MANDROVSKAJA, N.M., OKHRIMENKO, S.M., STARCHENKOV, V.I. 1994. Symbiotic properties of nodule bacteria of pea which form nodules against a background of high content of mineral nitrogen. Physiology and Biochemistry Cultural Plants, 26, 240-249. [in Russian]

MANDROVSKAYA, N.M., OKHRIMENKO, S.M., KIRIZIY, D.A., STARCHENKOV, V.I. 1995. Effect of inoculation by nitrogen-fixing clones of nodular bacteria on intensity of photosynthesis and nitrogen fixation in pea Physiology and Biochemistry Cultural Plants, 27, 169-173. [in Russian] 
MORGUN, V.V., CHEKALIN, N.M., BATASOVA, M.E., MIROSHNICHENKO, I.V. 2007. Actual state of breeding-genetic researches of pea. Physiology and Biochemistry Cultural Plants, 39, 3-13. [in Ukrainian] MORGUN, V.V., KOTS S.Ya. 2008. Symbiotic nitrogen fixation and its significance in nitrogen plant nutrition: research status and prospects. Physiology and Biochemistry Cultural Plants, 3, 187-205. [in Ukrainian]

MUNNE-BOSCH, S., WEILER, E.W., ALEGRE, L., MULLER, M., DUCHTING, P., FALK, J. 2007. $\alpha$-Tocopherol may influence cellular signaling by modulating jasmonic acid levels in plants. Planta, 225, 681-691. http://dx.doi.org/10.1007/s00425-006-0375-0

OKHRIMENKO, S.M. 2001. The pigment content in pea plants under inoculation by nodule bacteria, resistant to mineral nitrogen. Physiology and Biochemistry Cultural Plants, 33, 535-538. [in Ukrainian]

PATRIARCA, E.J., TATE, R., IOCCARINO, M. 2002. Key role of $\mathrm{NH}_{4}^{+}$ metabolism in Rhizobium-plant symbiosis. Microbiology and Molecular Biology Reviews, 66, 203-222. http://dx.doi.org/10.1128/mmbr.66.2.203-222.2002

PATYKA, V.P., KOTS, S.Ya., VOLKOGON, V.V. 2003. Biological nitrogen. Kyiv: Svit, 424 p. ISBN 966-7683-35-4 [in Ukrainian]

RHIJN, P., VANDERLEYDEN, J. 1995. The Rhizobium-plant symbiosis. Microbiological Reviews, 59, 124-142.

ROSSETTO, M., VANZANI, P., LUNELLI, M., SCARPA, M., MATTIVI, F., RIGO, A. 2007. Peroxyl radical trapping activity of anthocyanins and generation of free radical intermediates. Free Radical Research, 41, 854-859. http://dx.doi.org/10.1080/10715760701261533

SESSITSCH, A., HOWIESON, J.G., PERRET, X., ANTOUN, H. 2002. Advances in Rhizobium research. Critical Reviews in Plant Sciences, 21, 323378. http://dx.doi.org/10.1080/0735-260291044278

SPAYNK, G.; KONDOROSI, A.; HUKAS, P. 2002. The Rhizobiaceae, molecular biology of model plant-associated bacteria / Ed. TIKHONOVICH, I.A., PROVOROVA, N.A. St. Petersburg: Biont, 558 p. [in Russian]

TARCHEVSKY, I.A. 1996. The degradation process in plants. Soros Educational Journal, 6, 13-19. [in Russian]

TEPPER, E.Z., SHILNIKOVA, V.K., PEREVERZEVA, G.I. 1987. Practical Microbiology. Moscow: Kolos, 135 p. [in Russian]

TRAINER, M.A., CAPSTICK, D., ZACHERTOWSKA, A. 2010. Identification and characterization of the intracellular poly-3-hydroxybutyrate depolymerase enzyme PhaZ of Sinorhizobium meliloti, BMC Microbiology, 10, 1-92. http://dx.doi.org/10.1186/1471-2180-10-92

VOISIN, A.S., SALON, C., JEUDY, C., WAREMBOURG, F.R. 2003 Symbiotic $\mathrm{N}_{2}$ fixation activity in relation to $\mathrm{C}$ economy of Pisum sativum $\mathrm{L}$. as a function of plant phenology. Journal of Experimental Botany, 54, 2733-2744. http://dx.doi.org/10.1093/jxb/erg290

WALKER, T.S., BAIS, H.P., GROTEWOLD, E., VIVANCO, J.M. 2003. Root exudation and rhizosphere biology. Plant Physiology, 132, 44-51. http://dx.doi.org/10.1104/pp.102.019661

YAKYIMIV, M., ZAKLINSKI. O. 2005. Agrochemical and agroecological status of soils of the Ivano-Frankivsk district. Ivano-Frankivsk: 82 p.[in Ukrainian]

YOST, Ch.K., CLARK, K.T., DEL BEL, K.L., HYNES, M.F. 2003 Characterization of the nodulation plasmid encoded chemoreceptor gene mcpG from Rhizobium leguminosarum. BMC Microbiology, 3, 1-10. http://dx.doi.org/10.1186/1471-2180-3-1

ZHULIN, I.B., IGNATOV, V.V. 1986. Chemotaxis at Azospirillum brasilense in relation to amino acids. Microbiology, 55, 340-342. [in Russian] 